\section{TIHANA CEGUR RADOVIĆ IVANA VARIČAK ${ }^{2}$ NIKOLINA SMAJLA ${ }^{3}$ \\ ${ }^{1,2,3}$ Veleučilište u Karlovcu \\ ${ }^{1}$ tcradovic@vuka.hr \\ 2ivana.grgat@vuka.hr \\ 3nikolina.smajla@vuka.hr}

\title{
EDUCATION FOR SUSTAINABLE DEVELOPMENT AT UNIVERSITIES IN THE REPUBLIC OF CROATIA
}

\begin{abstract}
Sustainable development has become a leading paradigm in the late $20^{\text {th }}$ century when it became obvious that economic growth has a negative impact on the natural balance and social events, although its declared objective is the development of economy and society. The most frequently quoted definition is the one used by the World Commission on Environment and Development - WCED) as reported in 1987 in "Our Common Future", according to which 'Sustainable development is development that meets the needs of the present without compromising the ability of future generations to meet their own needs." The European Union has been supporting sustainable development for several decades already, and the new Europe 2020 strategy is the one for smart, sustainable and inclusive growth of all member states of the European Union. From the above it is evident how much importance the European Union attaches solely to sustainable development. Given the importance of sustainable development, it is becoming a subject of study at all levels of education is extremely significant, especially at the tertiary level. The subject of this paper is to examine the curricula of universities in the Republic of Croatia with the aim of analyzing the extent to which sustainable development is being studied and whether there are existing comprehensive interdisciplinary programs dealing with this issue.
\end{abstract}

Key words: sustainable development, education, high education.

\section{INTRODUCTION}

During last decades awareness of necessity to turn towards new development direction, sustainable development, is intensively growing. It evolved as a consequence of global and increasing ecological, social and economic problems. Sustainable development is making a balance between demand for life quality improvement, social welfare and peace for everyone and demand for preservation of environment components as properties on which actual and future generations depend. The preservation of Earth as a basis of life in all its diversity can be achieved by respecting the principles of democracy, gender equality, social justice, solidarity, respect of human rights and the preservation of natural resources, cultural heritage and the environment. In this way, sustainable development is achieved through a dynamic economy with full employment, economic, social and territorial cohesion, a high level of education of citizens, high level of protection of human health and the environment [11].

The European Union emphasizes the special importance of a sustainable development, and a new strategy for the period until 2020 highlights it. Strategy Europe 2020 seeks to encourage growth that is smart, which can be achieved by more efficient investments in education, research and innovation, sustainable by virtue of a decisive shift towards low carbon economy and inclusive which includes an emphasis on job creation and poverty reduction. The strategy has ambitious goals in five areas: employment, innovation, education, poverty reduction and climate / energy [13].

The application of the principles of sustainable development in all areas of economic and social life was followed by a growing number of declarations and action plans, which stress the importance of education, especially higher education, in applying the principles of sustainable development. A number of foreign authors like Holm, Sammalistoa, Grindsted and Vuarisaloa conducted a research related to the introduction of sustainable development in higher education [3]. Lozano et al. explored the implementation of sustainable development in higher education at the global level [4]. Sammalisto, Sundarstom and Holm examined the implementation of sustainability at universities in Sweden [8]. In Serbia, the sustainable development of higher education was researched by Vujičić and Ristić [9]. In Croatia, Črnjar and Črnjar [2] as well as Rončević and Rafajac dealt with the research of sustainable development in higher education [7]. They also introduce sustainable development in study programmes.

A number of arguments support the thesis that sustainable development needs to be studied, some of them are [1]: 
1. Education for sustainable development is a lifelong process; citizens should be at first informed and educated with the necessary knowledge and skills to solve the problem of sustainable development.

2. Sustainable development is a new way of looking at the environment in which students are taught about the connections that exist between nature and the environment, economy and social components. Students should understand that these components exist at local, regional and global levels.

3. Education for sustainable development deals with the dynamics of the physical, biological, social, economic, and social environment.

A number of foreign universities apply the principles of sustainable development in their daily activities. The application is carried out, not only through lesson plans that are dedicated to sustainable development, but also through the publication of scientific and professional papers, engaging in activities that promote the needs of the community, volunteering and organization of institution according to the standards of so called green organizations.

According to the importance of sustainable development, it is important that it becomes a subject of study at all levels of education, especially at tertiary level. The subject of this paper is to examine the curricula of universities in the Republic of Croatia with the aim of analyzing the extent to which the sustainable development is studied and whether there is a comprehensive interdisciplinary programs that deal with this issue. The main hypothesis is that in Croatia there are comprehensive interdisciplinary programs that teach sustainable development.

For the purpose of this paper methods of analysis, synthesis, description, compilation and comparison were used. The curricula of selected higher education institutions in Croatia were analyzed and compared. The method of compilation and description were used for explanation of historical development of education for sustainable development, and the above mention methods were also used to explain the sustainable development strategy of the Republic of Croatian. Synthetic method was used for final conclusions.

\section{HISTORY OF EDUCATION FOR SUSTAINABLE DEVELOPMENT}

Education and the development of science are crucial for promoting new ways of thinking and emphasizing social and environmental values, as well as for improving human capabilities to address environmental issues and development. For centuries, societies were developing successfully, providing that their educational systems devised high-quality educational programmes. Through educational industries the preconditions for the development and emergence of the knowledge society and the welfare society were met. The interaction of educational institutions and the welfare society points to the creation of the fundamental intellectual and material assumption for the growth of sustainable development [2].

Significant commitment to education for sustainable development began in the 90 s of the 20th century. The United Nations Conference on Environment and Development (UNCED) held in 1992 in Rio de Janeiro focused the world's attention on the most critical issues faced by the entire world and adopted Agenda 21 . Chapter 36 of Agenda 21 points out that education plays a key role in the challenges of sustainable development [10]. The conference has clearly shown that the environment and the economic and social development can no longer be thought of as separate categories. In 1997 the Declaration of Thessaloniki was signed by 83 countries, highlighting the need to develop public awareness and education for sustainable development [16]. The World Declaration on Higher Education for the Twenty-First Century: Vision and Action (1998) highlights the need for special skills and educated people in order to ensure sustainable development [1]. Apart from the statements of ethics and values for a sustainable future, The Earth Charter adopted by the UN in 2000 also includes education for sustainable development [1].

This is followed by the The Lüneburg Declaration and a number of other declarations supporting the role of higher education in education for sustainability. In 2002 under the leadership of Japan the United Nations General Assembly proclaimed the UN Decade of Education for Sustainable Development, 2005-2014, (DESD). After the adoption of the Declaration a strong growth of theoretical literature on sustainable development has been recorded, containing information and databases dealing with the role of universities and research in achieving sustainable development concept. The main objective of the Decade is to weave the principles, values and practices of sustainable development into all views of education and learning [6]. It encourages changes in behaviour so as to create a more secure future based on environmental integrity, economic viability, and a just society. At the 2009 G8 summit Universities issued a declaration on research and education for sustainability and responsible development at the local and global level [1]. The same year, the World Conference on Higher Education pointed the direction higher education should take in the future, and at the same time called for action [1]. In 2010 ASHE (The Association for the Advancement of Sustainability in Higher Education) calls for action by creating the sustainability curriculum in higher education [12]. The working group of 25 representatives of higher education, agencies, organizations, associations and student groups issued the people's agenda on sustainability of higher education in order to form a platform for cooperation after the Rio + 20 summit [1].

The goal of education for sustainable development is to help people develop the knowledge, skills and behaviors that will help them live sustainably and make 
decisions based on information that will promote the welfare of all and help to ensure the future.

\section{STRATEGY OF SUSTAINABLE DEVELOPMENT IN THE REPUBLIC OF CROATIA}

Environmental Protection Act from year 2007 has assigned Strategy of sustainable development in the Republic of Croatia, as a document that beams longterm economic and social development and environment protection toward sustainable development [18]. Strategy of sustainable development in the Republic of Croatia has been accepted in February 2009 by the Croatian parilament [15]. It includes main principles, appoints main goals and measures of sustainable development of economy, sustainable social development and environment protection, identifies central challenges in their achievements, and it is oriented to eight main areas on which strategic development directions of Croatia are based [15]. The Strategy emphasises the importance of raising educational level of all citizens, building a society based on knowledge and supporting a culture of research and investment in sustainable development.

Strategy of sustainable development observes three level of education for sustainable development [5]:

1. through formal education in educational institutions;

2. out of formal educational institutions, through for example non-government organizations (informal education);

3. through media (newspapers, television, radio) in order that education for sustainable development becomes a part of everyday life.

Existing curriculums of all levels of formal education have to be changed and adjusted to include principles and values of sustainability and interdisciplinary characteristics of its three components.

Integration of elements of sustainable development in development plans oft he Republic of Croatia still remained at declarative level and there is still no serious legislative intent to sistematically implement principles of sustainable development into development plans of the Republic of Croatia. There are only some references to sustainability in documents related to education [5].

\section{SUSTAINABLE DEVELOPMENT IN HIGHER EDUCATION OF THE REPUBLIC OF CROATIA}

Higher education systems (systems of tertiary education) have especially important role in global systems of education. These systems qualify excellent professionals, intelectuals, entrepreneurs, professors, scientists and managers in scientific fields: natural sciences, technical sciences, biomedicine and health, biotechnical sciences, social sciences, humanistic sciences and artistic domain. Higher education determines primary role and importance in globaly sustainable development of primary, secondary, tertiary, scientific and quinary business as circulation and nervous system of nowadays civilization [2].

In the Republic of Croatia tertiary education is organised as so-called binary system where professsional and scientific university studies are performed. Professional studies in the Republic of Croatia are giving students a level of knowledge and skills to transact professional business and qualify them for entering production and services sector. Professional studies are preformed at polytechnics and universities of applied sciences, uniquely at universities [17]. Students of professional studies should get aplicative and operative knowledge and skills from their profession and from sustainable development. They should learn how to implement and conduct measures and activities of sustainable development.Those programmes should be adjusted to specific scientific field and science branch. Undergraduate university programmes in the Republic of Croatia last three to four years. Students enrolled in undergraduate university programmes at faculties of natural, technical, biomedicine, biotechnical, social and humanistic sciences in specific fields and branches acquire explicit, implicit and disciplinary knowledge and siklls about environment protection and sustainable development [2]. Students that have graduated from adequate undergraduate university studies are enrolled in graduate university studies. At this studies students are trained and specialized at adequate profession and vocation at specific scientific fields and science branches: natural, technical, biomedicine, biotechnical, social and humanistic sciences [2]. After graduation of graduate university study it is possible to enroll in specialist postgraduate or doctoral study programmes to achieve the highest level of formal education. Students that have graduated at adequate graduate university studies are enrolled at specialist postgraduate studies, that last one or two years. Those studies should be organized for education of specialists for ecologial phenomena, operative ecological managers, for carriers of ecological politics in companies, for edcators at professional studies or teachers at high schools [2]. After analyzing programmes of specialist postgraduate studies, it is noted that there is a small amount of specialist postgraduate studies of ecology and sustainable development. That should be a challenge to higher education institutions of adequate scientific fields of natural, technical, biotechnical, social and humanistic sciences. Those specialists should be formers of ideas about global sustainable development and they should be creating, designing, operationalizing and controlling applicative and development researches in global economic systems.

The latest classification of science offers legal and educational framework for the introduction of special university programmes comprising environmental facilities [2]. Almost every higher education institution 
deals with current environmental problems and problems of sustainable growth and development. These issues are being dealt with within special mandatory or elecive programmes (or courses), or as a part of special thematic units of corresponding programmes [2]. According to the rulebook on scientific and artistic areas, fields and branches, specific branches of science were determied, in which more programmes with environmental content can be designed. These are: scientific field of biology, special branch ecology; scientific field of interdisciplinary natural science, special branch environmental science; scientific field of chemical engineering, special branch environmental protection in chemical engineering; scientific field of agriculture, special branch ecology and environmetal protection; scientific field of forestry, special branches urban forestry and nature protection, and special branch ecology and silviculture [14]. This does not mean that other scientific fields, especially the scientific field of economics, lack possibilities for introducing special branches that would deal with sustainable development.

\section{The purpose of researching university curricula in the Republic of Croatia in terms of opportunities to achieve sustainable development}

The subject of this paper is to examine the university curricula in the Republic of Croatia with the aim of analyzing the extent to which sustainable development is being studied and to determine whether there are comprehensive interdisciplinary programs dealing with the issue. The study was conducted by analyzing curricula available on the websites of the Universities of Zagreb, Osijek, Rijeka, Zadar, Split, Dubrovnik, Pula and the Croatian Catholic University. A deliberate pattern of Faculties of Economics and Business curricula in Croatia was also used, including the curricula of undergraduate, graduate, postgraduate specialist and doctoral studies in Zagreb, Rijeka, Osijek, Split, Pula and Dubrovnik.

\section{Research analysis results}

By analyzing the curricula of the Faculties of Economics in Rijeka [19], Osijek [20], Split [21], Zagreb [22], the Faculty of Economics and Tourism "Dr. Mijo Mirković" in Pula [23], The Faculty of Tourism and Hospitality Management in Opatija [24] and the Department of Economics and Business, University of Dubrovnik [25] that are available on the website of these faculties, it can be concluded that the only faculty performing a comprehensive interdisciplinary programs of sustainable development is the Faculty of Tourism and Hospitality Management in Opatija. At the undergraduate level there is a study in Sustainable Development Management, at the graduate level there is a study in Sustainable Development of Tourism and the postgraduate doctoral level one can also study the Sustainable Development Management.

Faculty of Economics and Business in Zagreb offers only elective courses covering sustainable development as a part of their studies, these being Environmental Protection Management at the undergraduate level and Corporate Social Responsibility at the graduate level.

Faculty of Economics in Split offers an elective course in Environmental Economics at the graduate level of Economics, as a part of their Economic Policy and Financial Markets programme. As a part of their International Economics and European Integration programme they offer a mandatory course in Environmental Economics. Faculty of Economics and Tourism "Dr. Mijo Mirković" in Pula offers a course in Sustainable Development Management as a part of their Management and Enterpreneurship undergraduate programme, as well as the course in Sustainable Tourism Management as a part of their Culture and Tourism interdisciplinary programme. As a part of Human Resources and Knowledge Society postgraduate programme there is a course in Corporate Social Responsibility Management, and as a part of European Integration, Regional and Local Economic Development programme, a course in Corporate Social Responsibility in the Public Sector is offered. Other faculties of Economics do not offer the courses covering sustainable development in their curricula.

Table 1. Analysis of the study of sustainable development at the Faculties of Economics of the Universities in Croatia

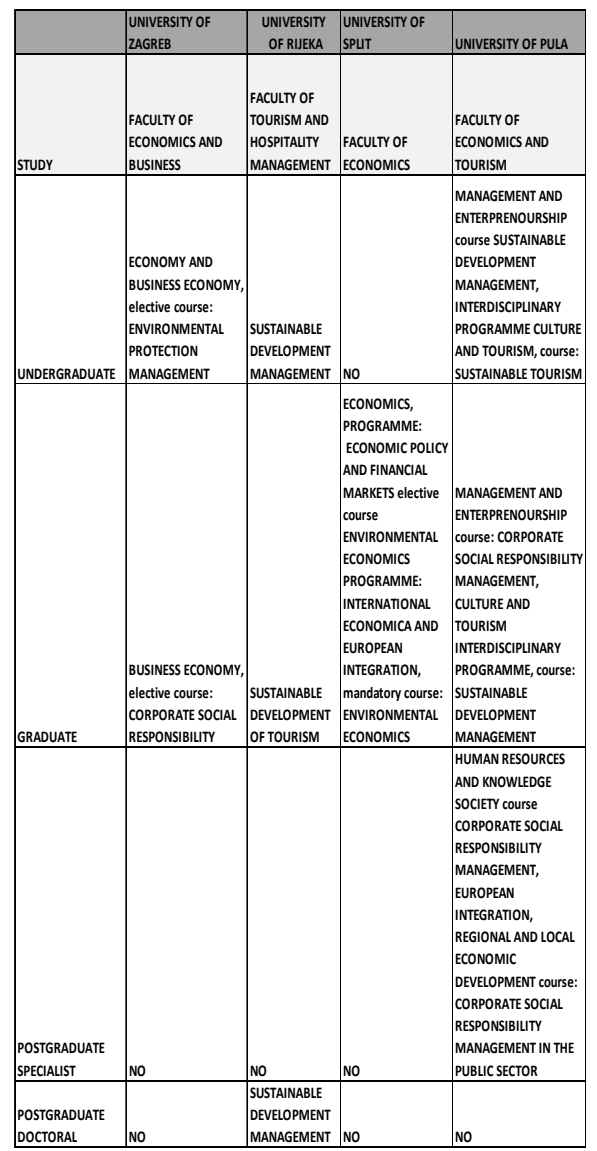


By analyzing the study of sustainable development at the Faculties of Economics in Croatia it can be concluded that there are existing interdisciplinary programmes dealing with the questions of sustainable development. However, comprehensive interdisciplinary programmes are offered at only one faculty at the University of Rijeka, which is not enough. Therefore, it is necessary to implement the study of sustainable development at other universities in the Republic of Croatia as well.

\section{CONCLUSION}

The role of universities and higher education institutions in promoting sustainable development is crucial because it is both about educating people who will make development decisions as managers in companies, and about educating people who will educate the younger generations as university professors.

After analysis of the study of sustainable development at the universities in the Republic of Croatia it can be concluded that sustainable development is being studied at the universities, but only a small number of curricula, especially at the Faculties of Economics, comprises courses on sustainable development. Courses on sustainable development are mostly elective and it is necessary to introduce more compulsory courses with the theme of sustainable development. Only one faculty in the Republic of Croatia, Faculty of Tourism and Hospitality Management in Opatija at the University of Rijeka, has an integrated interdisciplinary program that addresses the issues of sustainable development. Therefore, it is necessary to develop more interdisciplinary programs dealing with the study of sustainable development, at least one at each university, which also entails the training of professional staff who would deal with these issues.

\section{REFERENCES}

[1] Črnjar, K.: Doprinos visokoga obrazovanja razvoju i implementaciji obrazovanja za održivi razvoj, http://www.zavod.pgz.hr/pdf/6_doc.dr.sc.Kristina_CRNJAR. pdf, (05.03.2016.)

[2] Črnjar, M., Črnjar, K.: Menadžment održivog razvoja, Fakultet za menadžment u turizmu i ugostiteljstvu u Opatiji Sveučilišta u Rijeci, Glosa, Rijeka, 2009.

[3] Holm, T., Sammalisto, K., Grindsted, T. S., Vuarisalo, T.: Process framework for indentifying sustainability aspects in university curriculum and integrating education for sustainable development, Journal of Cleaner Production 106 (2015), 164-174.

[4] Lozano, R., Ceulemans, K., Alonso-Almeida, M., Huisingh, D., Lozano, F. J., Waas, T., Lambrechts, R., Huge, J.: A rewiew of commitment and implementation of suistainable development in higher education: resoult from a worldwide survey, Journal of Cleaner Production, 108 (2015), 1-18.

[5] Matešić, M.: Principi održivog razvoja u strateškim dokumentima Republike Hrvatske, Soc. Ekol. Zagreb, 18 (2009), 323-339.
[6] Pavić Rogošić, L.: Održivi razvoj, http://odraz.hr/media/21831/odrzivi_razvoj.pdf (12.04.2016.)

[7] Rončević, N., Rafajac., B.: Održivi razvoj izazov za sveučilište?, Filozofski fakultet u Rijeci, Rijeka, 2012.

[8] Sammalisto, K., Sundarstom, A., Holm, T.: Implementation of sustainability in universities as perceoived by faculty and staff - a model from an Swedish university, Journal of Cleaner Production, 106 (2015) 45-54.

[9] Vujičić, M., Ristić, L.: Higher education system of the Republic of Serbia in support of sustainable development: Challenges of the EU integration, Megatrend revija, 12 (2015), 139-156.

\section{Regulations}

[10] Agenda 21 (1992.),

https://sustainabledevelopment.un.org/content/documents/Ag enda21.pdf (11.04.2016)

[11] Akcijski plan za obrazovanje za održivi razvitak, Ministarstvo zaštite okoliša, prostornog uređenja i graditeljstva, Zagreb, 2011., www.mzoup.hr

[12] The Association for the Advancement of Sustainability in Higher Education, http://www.aashe.org/ (12.04.2016.)

[13] Europska komisija: Strategija Europa 2020, http://ec.europa.eu/europe2020/europe-2020-in-anutshell/priorities/index_hr.htm (14.04.2016.)

[14] Pravilnik o znanstvenim i umjetničkim područjima poljima i granama, Narodne novine br. 118/09, 82/12 i 32/13

[15] Strategija održivog razvitka Republike Hrvatske, http://narodne-

novine.nn.hr/clanci/sluzbeni/2009_03_30_658.html (05.03.2016.)

[16] Ujedinjeni narodi: Strategija gospodarske komisije Ujedinjenih naroda za Europu za obrazovanje za održivi razvoj,

https://www.unece.org/fileadmin/DAM/env/esd/strategytext/ Srategy.Croatian.pdf (12.03.2016.)

[17] Zakon o znanstvenoj djelatnosti i visokom obrazovanju, Narodne novine 2003, 198, 2004, 174, 2007, 46, 2009, 45, 2011, 63, 2013, 139, 2014, 101, 2015, 60

[18] Zakona o zaštiti okoliša, Narodne novine, br. 110/07.

\section{The Internet}

[19] Ekonomski fakultet Rijeka, https://www.efri.uniri.hr/ (05.03.2016.)

[20] Ekonomski fakultet u Osijeku, http://www.efos.unios.hr/ (05.03.2016.)

[21] Ekonomski fakultet u Splitu, https://www.efst.hr/ (05.03.2016.)

[22] Ekonomski fakultet Zagreb, http://www.efzg.unizg.hr (05.03.2016.)

[23] Fakultet ekonomije i turizma „Dr. Mijo Mirković“ Pula, http://fet.unipu.hr/ (05.03.2016.)

[24] Fakultet za menadžment u turizmu i ugostiteljstvu Opatija, http://www.fthm.uniri.hr/ (05.03.2016.)

[25] Odjel za ekonomiju i poslovnu ekonomiju Sveučilišta u Dubrovniku, http://www.unidu.hr/odjeli.php?idizbornik=31 (05.03.2016.) 


\section{BIOGRAPHY}

Tihana Cegur Radovic, univ.spec.oec., was born on December 4, 1978 in Karlovac. After finishing Secondary School of Economics in Karlovac she enrolled the Faculty of Economics and Business, department of Marketing, at the University of Zagreb, where

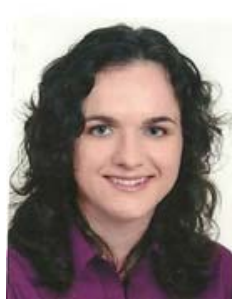
she achieved her MA in Economics in 2004. In September 2007, she started attending Postgraduate Specialist Studies in Marketing Management. By the end of 2009 she successfully defended her dissertation entitled "Public Relations in Banking Sector". Since 2010 she has taught college courses and practicums on the Fundamentals of Marketing and Marketing in the Hospitality Industry as an external associate. She has acquired her lectureship in 2014, in the field of Economics, the branch of Marketing. Since July 2015, she holds the position of permanent lecturer at the Karlovac University of Applied Sciences where she teaches the Fundamentals of Marketing, Marketing in the Hospitality Industry, Running Hospitality Business and Tourist Market Research. Presently she studies at Postgraduate Doctoral Studies, Management of Sustainable Development at Faculty of Tourism and Hospitality Management in Opatija. She is the author and co-author of scientific and professional articles published in the Collected Works.

\section{OBRAZOVANJE ZA ODRŽIVI RAZVOJ NA SVEUČILIŠTIMA REPUBLIKE HRVATSKE Tihana Cegur Radović, Ivana Varičak, Nikolina Smajla}

Rezime: Europska unija se već nekoliko decenija zalaže za održivi razvoj, a nova strategija Europa 2020 je strategija za pametan, održiv i uključiv razvoj svih zemalja Europske unije. Kao članica EU, Republika Hrvatska posebnu pažnju posvećuje ovom konceptu. U radu su predstavljeni rezultati istraživanja nastavnih planova $i$ programa s ciljem analize zastupljenosti sadržaja koji se odnose na problematiku održivog razvoja i utvrđivanja podataka o interdisciplinarnim kursevima iz ove oblasti na sveučilištima u Republici Hrvatskoj.

Ključne reči: održivi razvoj, obrazovanje, sveučilište. 